\title{
Analisis Bentuk Musikal dan Struktur Lagu Tanah Airku Karya Ibu Soed Aransemen Joko Suprayitno untuk Duet Vokal dan Orkestra
}

\author{
Puput Meinis Narselina \\ Alumni Jurusan Musik FSP ISI Yogyakarta \\ R. Taryadi \\ Fakultas Seni Pertunjukan ISI Yogyakarta \\ Yc.Budi Santosa \\ Fakultas Seni Pertunjukan ISI Yogyakarta
}

\begin{abstract}
Analysis of the music is learning to find some of the elements of music which in principle covers all aspects of music, among others; melody, harmony, rhythm, dynamics, and forms of music. This paper is an analysis of musical form and structure of Tanah Airku song from Ibu Soed arrangement works by Joko Suprayitno for vocal duet and orchestra format. This research method is a type of qualitative research methods with musicological approach to the arranger. The method includes a historical review, analysis of musical form and structure of the arrangement. This study aims to determine the musical form and structure of Tanah Airku song arrangement by Joko Suprayitno for vocal duet and orchestra.
\end{abstract}

Keywords: Joko Suprayitno, Analysis of Arrangement of My Tanah Air Song by Ibu Soed.

\begin{abstract}
Abstrak
Analisis dalam musik adalah pembelajaran untuk menemukan beberapa elemen - elemen musik yang pada prinsipnya meliputi semua aspek dari musik antara lain; melodi, harmoni, ritme, dinamika, dan bentuk musik. Karya tulis ini merupakan analisis bentuk musikal dan struktur lagu Tanah Airku karya Ibu Soed aransemen Joko Suprayitno untuk format duet vokal dan orkestra. Metode penelitian ini merupakan jenis metode penelitian kualitatif dengan pendekatan musikologis kepada arranger. Metode tersebut meliputi tinjauan historis, analisis bentuk musikal dan struktur aransemen. Penelitian ini bertujuan untuk mengetahui bentuk musikal dan struktur lagu Tanah Airku karya Ibu Soed aransemen Joko Suprayitno untuk duet vokal dan orkestra.
\end{abstract}

Kata kunci: Joko Suprayitno, Analisis Aransemen Lagu Tanah Airku karya Ibu Soed

\section{Pengantar}

Dewasa ini mulai tumbuh kesadaran orangtua dalam memberikan kesempatan kepada anak-anaknya untuk mempelajari musik walaupun tujuannya bukan sematamata untuk menjadi pemusik profesional, tetapi lebih ditekankan untuk pembentukan watak baik. Tumbuhnya kesadaran orangtua itu ditunjang oleh banyaknya informasi yang mudah diserap tentang manfaat musik dari hasil penelitian yang sudah dilakukan. Sarana untuk mempelajari musik juga telah tersedia, baik berupa instrumen musik maupun tempat kursus-kursus musik yang menyediakan berbagai pilihan bagi orangtua dan anak dalam mempelajari instrumen yang diminati.

Musik adalah bahasa universal 
yang banyak digemari oleh masyarakat. Musik yang disusun sedemikian rupa akan menghasilkan suara yang mengandung harmoni, irama, dan lagu dari alat-alat yang dapat menghasilkan irama. Joko Suprayitno adalah seorang arranger, pemain trombone dan juga aktif dalam berbagai kegiatan musik diantaranya, musik klasik, Pop, dan Jazz. Selain itu juga Joko berprofesi sebagai dosen tetap di Institut Seni Indonesia Yogyakarta, Fakultas Seni Pertunjukan, Jurusan Seni Musik sebagai dosen mayor trombone dan ensembel tiup. Joko pernah mengaransemen Brass Ensembel untuk Marching Band Saraswati Institut Seni Indonesia Yogyakarta pada kompetisi Grand Prix Marching Band ke-XXIXn tahun 2013 lalu dan mendapat piala juara 3 divisi Utama dalam kategori Musik Terbaik dari 23 peserta Marching Band se-Indonesia dengan mengusung tema The Legend of Peer Gynt Suite dimana ensemble Brass keseluruhan diaransemen oleh Joko Suprayitno.

Joko juga arranger tetap pada kelompok musik Jakarta Philharmonic Orchestra dan lagu yang pernah diaransemen oleh Joko adalah lagu Tanah Airku karya Ibu Soed yang dimainkan oleh Jakarta Philharmonic Orchestra (JPO) dalam konser bertajuk The Notes of Eternity A Tribute to Historical Musical Journey, pada hari Sabtu 21 April 2012 di Aula Simfonia, Kemayoran Jakarta pukul 19.30 WIB.

Mengenal beberapa istilah-istilah penting dari unit-unit struktur bentuk musikal diantaranya ada figur, motif, semifrase, frase, kadens dan periode. Didalam semua struktur musik tersebut jika dijadikan menjadi satu akan membentuk sebuah kalimat musik dan merupakan satu kesatuan musik yang biasa disebut dengan bentuk bagian lagu. Figur adalah unit terkecil dari bentuk musik yang mengandung sedikitnya sebuah karakteristik ritme dan satu karakteristik interval.
Biasanya, figur terdiri dari minimal dua nada dan maksimum dua belas nada serta dapat dipertimbangkan sebagai sebuah unit tunggal.

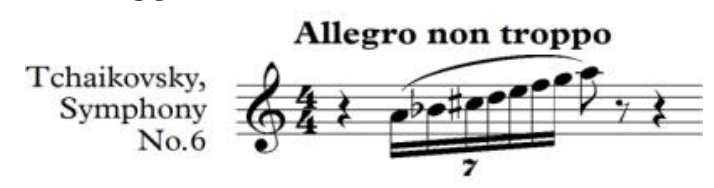

Notasi 1. Contoh figur2

Istilah motif digunakan sebagai persamaan dari figur. Yang membedakan diantara keduanya yaitu figur sebagai suatu unit pengiring atau pola tertentu seperti yang terdapat pada karya-karya etude atau iringan Barok, sedangkan motif adalah sebagai suatu partikel tematik.3

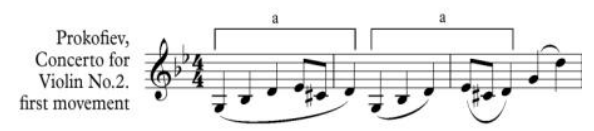

Notasi 2. Contoh motif4

Semifrase tersusun atas beberapa figur-figur yang menjadi motif. Sedangkan frase adalah suatu unit yang dibagi dalam dua semifrase dimana dalam musik secara umum terdiri dari empat birama dan berakhir dengan sebuah kadens.5 Sebuah frase dalam musik, dapat dianalogikan dengan sebuah kalimat dalam prosa. Frase memiliki panjang atau durasi yang beragam, namun secara umum ukuran frase adalah empat birama. Jenis-jenis frase yakni ada frase anteseden dan frase konsekuen. Frase anteseden secara karakteristiknya disebut juga kalimat tanya. Sedangkan frase konsekuen secara karakteristik disebut juga kalimat jawaban.

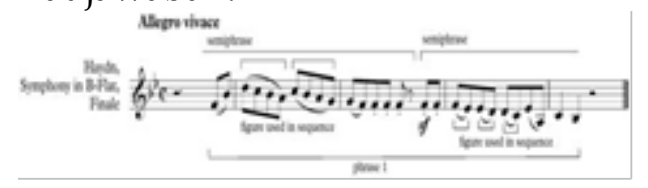

Notasi 3. Contoh semifrase dan frase6

Periode atau disebut dengan bentuk kalimat (sentence form) merupakan unit yang didalamnya terdiri dari dua frase, yakni 
frase anteseden dan frase konsekuen. Frase anteseden bersifat interogatif yang secara umum diakhiri oleh kadens non-final dalam musik tonal biasanya disebut dengan kadens setengah.

Bentuk lagu tiga bagian adalah bentuk satu lagu yang memuat tiga kalimat atau periode kontras satu dengan yang lainnya. Kontrasnya dapat dilihat dari segi:

a. kontras dalam irama,

b. kontras dalam arah melodi,

c. kontras dalam jenis tangga nada,

d. kontras dalam modulasi ke dominan atau minor dan lain sebagainya.7

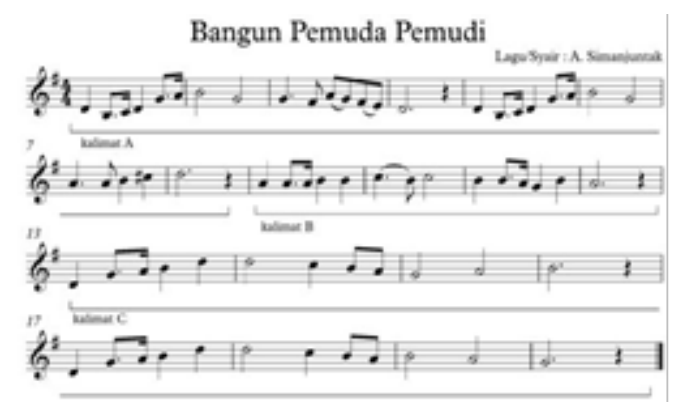

Notasi 4. Contoh bentuk lagu tiga bagian

Dalam mengaransemen sebuah lagu, ada beberapa hal yang perlu diperhatikan yakni mencakup pengembangan variasi baik melodi irama, harmoni, bentuk

aransemen dan kreativitas lainnya yang disesuaikan dengan gaya lain dengan tidak keluar dari jalur karakter melodi yang asli. Dengan demikian variasi termasuk teknik yang memegang peranan paling penting dalam membuat suatu komposisi atau mengaransemen sebuah lagu.

\section{Pembahasan}

\section{A. Analisis Bentuk Musikal dan Struktur} Lagu Tanah Airku karya Ibu Soed

Lagu Tanah Airku karya Ibu Soed dibuat dengan tanda sukat 4/4 dalam tangga nada C Mayor dan bertempo Largo yakni tempo lambat kecepatan antara 44-48 ketukan. Melodi dimulai dari Up-beat ketukan ketiga pada birama pertama, dengan jumlah biramanya adalah 12 birama. Tanah
Airku karya Ibu Soed merupakan lagu dengan bentuk tiga bagian atau Three Part Song Form yang artinya lagu dengan tiga kalimat yang berlainan

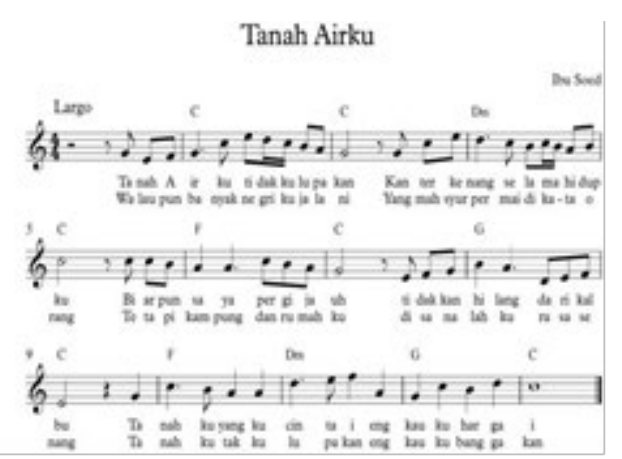

Notasi 5. Melodi dan Akord Lagu

Tanah Airku karya Ibu Soed9

Berdasarkan notasi diatas dapat dilihat luas wilayah nada lagu dimana nada paling tinggi adalah nada $\mathrm{F}$ dan nada paling rendah terletak pada nada $\mathrm{D}$ tengah. Lagu Tanah Airku ini termasuk bentuk lagu tiga bagian yang pendek karena hanya dibuat dalam 12 birama saja, penjabarannya adalah setiap kalimat hanya memiliki 4 birama yakni periode A (birama 1-4), periode B (birama 5-8), dan periode C (birama 9-12).

Akord-akord yang terdapat dalam lagu Tanah Airku karya Ibu Soed ini adalah sebagai berikut $\mathrm{C}$ Mayor (I), d minor (ii), $\mathrm{F}$ Mayor (IV), dan G Mayor (V). Maka dapat disimpulkan bahwa progresi akord lagu Tanah Airku yakni I-I-ii-I - IV-I-V-I - IV-ii-VI (berdasarkan notasi 5).

\section{A.1. Periode A}

Melodi pokok pada periode A, dimulai dari up-beat ketukan ketiga birama pertama. Didalam satu kesatuan Periode A ini dijumpai beberapa motif. Bisa disebut motif jika nada-nada yang menjadi satu kesatuan dapat berdiri sendiri dan akhirnya menjadi partikel tematik. Motif sebagai sebuah porsi tematik yang didalamnya terdiri dari dua atau tiga figur. Motif biasanya mengalami pengulangan atau pengolahan. Misalnya saja pada lagu Tanah Airku bagian pertama ini ditemukan ada 4 motif dan diilustrasikan dengan angka yakni: 
motif 1 , motif 2 , motif 3 , dan motif 4 . Penjelasannya adalah motif 1 gerak ritmenya sama dengan motif 3 , sedangkan motif 2 gerak ritmenya sama dengan motif 4 . Tetapi motif 1-motif 3 dan motif 2-motif 4, gerakan nadanya berlawanan dimana motif 1 bergerak kebawah sedangkan motif 3 bergerak keatas, begitu juga dengan motif 2motif 4. Oleh karena itu, motif yang ada didalam Periode A ini bisa dikatakan sebagai motif gerak berlawanan atau contrary.

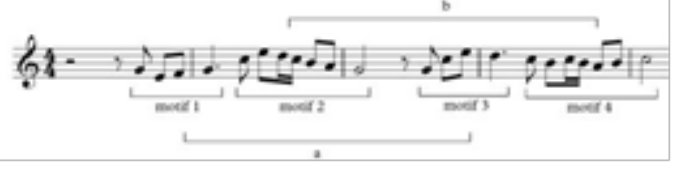

Notasi 6. Motif periode A, birama 1-4

Frase ada 2 jenis yakni frase anteseden atau kalimat tanya dan frase konsekuen atau kalimat jawaban. Dapat dikatakan sebagai frase jika setiap frase dipisahkan oleh sebuah kadens, dimana biasanya frase anteseden dipisah oleh kadens yang tidak selesai atau kadens setengah sedangkan frase konsekuen bersifat lebih tegas karena dipisah oleh kadens autentik atau kadens sempurna.

Seperti pada periode A ini, terdapat 2 frase yakni frase anteseden dan frase konsekuen. Walaupun kadens pada frase anteseden adalah akord C (I), tetapi jika melodi pada nada sopran adalah nada kwint, tetap dikatakan bahwa akhir daripada frase anteseden ini adalah kadens tidak sempurna. Kemudian pada frase konsekuen dimana merupakan kalimat jawaban dari frase anteseden biasanya terdapat kadens autentik atau kadens sempurna.

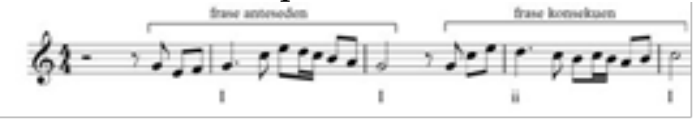

Notasi 7. Frase periode A, birama 1-4

Jika sudah diketemukan frase anteseden dan frase konsekuen, maka pada bagian ini bisa dikatakan sebagai satu kalimat utuh dimana jika frase anteseden dan frase konsekuen menjadi satu kesatuan akan terbentuk satu bentuk kalimat (sentence form). Oleh karena itu periode A ini merupakan kalimat pertama dari lagu Tanah Airku karya Ibu Soed. Seperti yang terlihat pada penjabaran dibawah ini:

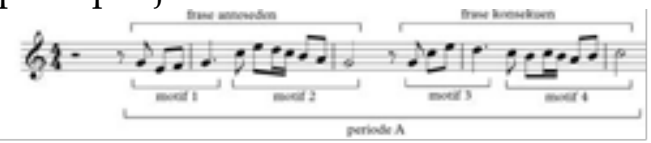

Notasi 8. Struktur lagu Tanah Airku periode A, birama 1-4

A.2. Periode B

Melodi pokok dengan motif baru, dimulai dengan nada dan ritmis yang beda daripada periode A. Nada pertama pada periode $\mathrm{B}$ dibuat mulai dari up-beat ketukan ketiga birama keempat lagu Tanah Airku. Didalam satu kesatuan Periode B ini juga dijumpai beberapa motif. Berikut penjelasannya, dimana ditemukan terdapat 4 motif baru dan masih sama seperti pada periode A motif pada periode B diilustrasikan dengan angka yakni: motif 5, motif 6 , motif 7 , dan motif 8 . Penjabarannya adalah motif 5 gerak ritmenya sama dengan motif 7 , sedangkan motif 6 gerak ritmenya sama dengan motif 8 . Tetapi pada motif 5motif 7 dan motif 6-motif 8, gerakan nadanya berlawanan maksudnya adalah walaupun ritmenya sama tapi melodi pada motif 5 berjalan gerak kebawah sedangkan melodi pada motif 7 gerak keatas, begitu juga sama dengan motif 6- motif 8 . Oleh karena itu, motif yang ada didalam Periode B ini juga bisa dikatakan sebagai motif gerak berlawanan atau contrary.

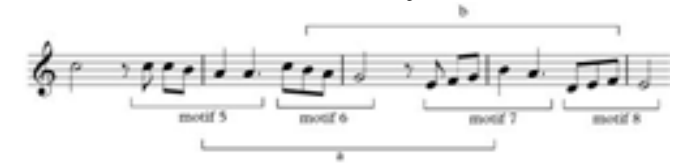

Notasi 9. Motif periode B, birama 5-8

Setelah penjabaran mengenai motif pada periode B, maka terbentuklah frase. Seperti yang terlihat pada periode B ini, terdapat 2 frase yakni frase anteseden dan frase konsekuen. Bisa dinyatakan sebagai frase karena didalam frase anteseden dan frase konsekuen mengandung motif-motif yang terbentuk dari partikel-partikel figur. Masih sama dengan periode A dimana pada 
periode B ini dalam satu frase hanya terdapat 2 birama yakni frase anteseden (birama 5-6) dan frase konsekuen (birama 7-8)

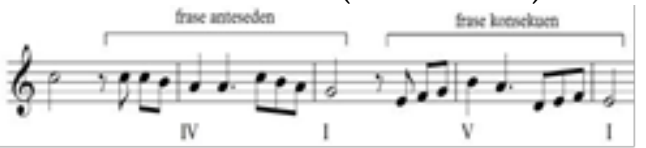

Notasi 10. Frase periode B, birama 5-8

Jika sudah diketemukan frase anteseden dan frase konsekuen, maka pada bagian ini bisa dikatakan sebagai satu kalimat utuh dimana jika frase anteseden dan frase konsekuen menjadi satu kesatuan dan membentuk satu bentuk kalimat (sentence form). Oleh karena itu periode $B$ ini merupakan kalimat kedua dari lagu Tanah Airku karya Ibu Soed.

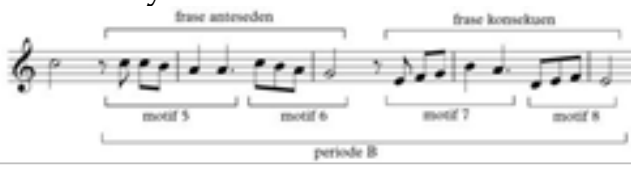

Notasi 11. Struktur lagu Tanah Airku periode B, birama 5-8

\section{A.3 Periode C}

Dirasa masih segar karena selalu membawakan motif baru pada setiap kalimatnya, melodi pokok pada periode $\mathrm{C}$ lagu Tanah Airku ini dimulai dari ketukan keempat birama kedelapan. Didalam satu kesatuan Periode $C$ ini dijumpai beberapa motif dan berbeda dengan periode $\mathrm{A}$ dan periode $\mathrm{B}$, akhir kalimat pada periode $\mathrm{C}$ ini dibuat dari beberapa figur kecil yang menarik. Motif yang terdapat pada periode C ini hanya ada 2 motif saja dan diilustrasikan dengan angka yakni: motif 9 dan motif 10 . Sedangkan dua birama terkahir yakni

birama 11 dan birama 12 menggunakan pola melodi kecil yang biasa disebut dengan figur.

Nada pada motif 9 dimulai dari birama 8 ketukan keempat dan terlihat jelas bahwa gerak ritmenya sama dengan pada motif 10 namun gerakan melodinya berlawanan dimana motif 9 bergerak kebawah sedangkan motif 10 bergerak keatas. Oleh karena itu, motif pada birama 9 dan birama 10 yang ada didalam Periode A ini bisa dikatakan sebagai motif gerak berlawanan atau contrary.

Lalu, berbeda pula dengan birama 11 dan birama 12 yang terdapat nada seperempat yang bergerak naik, nada seperempat ini tidak bisa dikatakan sebagai motif karena tidak dapat berdiri sendiri dan dengan jelas dapat dilihat bahwa nada seperempat ini bukan merupakan pertikel tematik. Maka, pada birama terakhir yakni birama 11 dan birama 12 pada lagu Tanah Airku merupakan gabungan dari figur-figur. Figur yang dimaksud adalah figur sekuen yang telah di modifikasi dimana gerakan melodinya bergerak naik. Dapat dilihat dari contoh motif dan figur pada periode C dibawah ini:

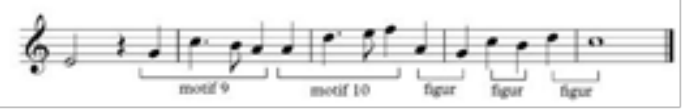

Notasi 12. Motif periode C, birama 9-12

Setelah dijabarkan mengenai motif dan figur yang ada pada periode $C$, maka terbentuklah frase. Seperti pada periodeperiode sebelumnya, periode $C$ ini terdapat pula 2 frase yakni frase anteseden dan frase konsekuen.

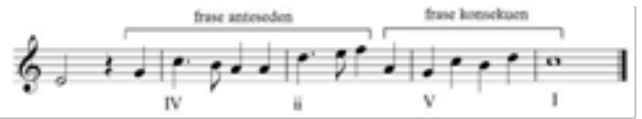

Notasi 13. Frase periode C, birama 9-12

Yang terakhir setelah diketemukan frase anteseden dan frase konsekuen, maka pada bagian ini bisa dikatakan sebagai satu kalimat utuh dimana jika frase anteseden dan frase konsekuen menjadi satu kesatuan akan terbentuk satu bentuk kalimat (sentence form). Oleh karena itu periode C ini merupakan kalimat ketiga dari lagu Tanah Airku karya Ibu Soed.

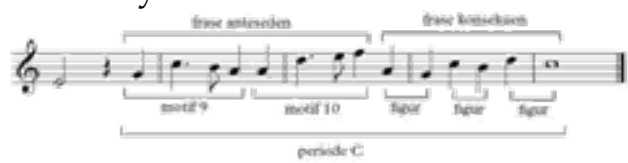

Notasi 14. Struktur lagu Tanah Airku periode C, birama 9-12

Dan dapat disimpulkan bahwa lagu Tanah Airku karya Ibu Soed dibuat dalam bentuk lagu tiga bagian atau Three Part Song 
Form namun dalam bentuk kalimat pendek karena setiap kalimat hanya dibuat sepanjang 4 birama saja dan masing-masing kalimat selalu membentuk kalimat baru yang berlainan satu sama lainnya. Berikut skema singkat bentuk lagu Tanah Airku karya Ibu Soed:

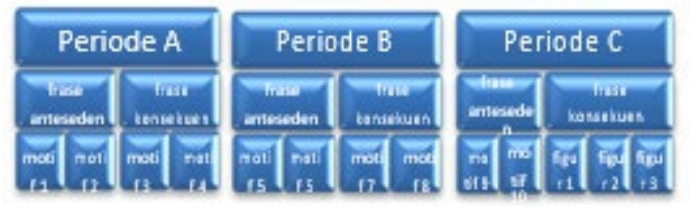

Gambar 1. Skema bentuk lagu Tanah Airku karya Ibu Soed

\section{B. Analisis Bentuk Musikal dan Struktur Lagu Tanah Airku Aransemen Joko Suprayitno}

Format besar dari Jakarta Philharmonic Orchestra merupakan orchestra yang menggunakan perluasan penggunaan ragam alat musik dibandingkan dengan orkes simfoni yang peralatan musiknya terbatas dan orkes ini merupakan orkestra dengan gaya baru dalam susunan formasi orkes simfoni yang terdiri dari instrumen lengkap diantaranya: Flutes, Oboes, Clarinets in Bes, Bassons, Horns in F, Trumpet in Bes, Trombones, Tuba, Timpani, Cymbals, Grand Cassa, Harp, Vokal, Violin, Viola, Violoncello, dan Contrabass.

Lagu Tanah Airku aransemen Joko Suprayitno ini dibuat menggunakan nada dasar C Mayor, tanda sukat 4/4 sepanjang 63 birama dan diawali dengan tempo andante (60) yang artinya tempo menengah, kemudian terjadi modulasi atau peralihan nada dasar dari C Mayor ke A Mayor dimana bagian ini merupakan bagian dari variasi 1 yang dibuat oleh Joko dan menggunakan tempo menengah sedikit lebih cepat dari tempo sebelumnya yakni menjadi andante moderato (65). Lalu terjadi variasi lagi yang ke-2 dengan peralihan modulasi dari A Mayor ke D Mayor dengan kembali ke tempo awal yakni andante (60). Kerangka Lagu Tanah Airku aransemen oleh Joko Suprayitno ini adalah sebagai berikut: Introduksi, Bagian A, Bagian B, Bagian C, dan Bagian D.

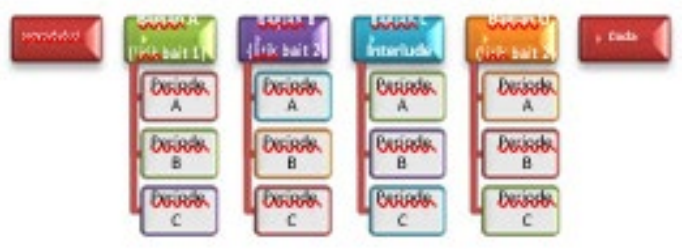

Gambar 2. Skema bentuk lagu Tanah Airku aransemen Joko Suprayitno

\section{B.1. Introduksi}

Introduksi pada Lagu Tanah Airku yang diaransemen oleh Joko dengan nada dasar C Mayor dibuat dalam 7 birama. Introduksi yang dibuat oleh Joko ini tidak mengalami perubahan yang sangat signifikan dari melodi asli, melainkan ada pengembangan harmonisasi dalam progresi akordnya. Introduksi mengambil tema dari Periode C lagu Tanah Airku.

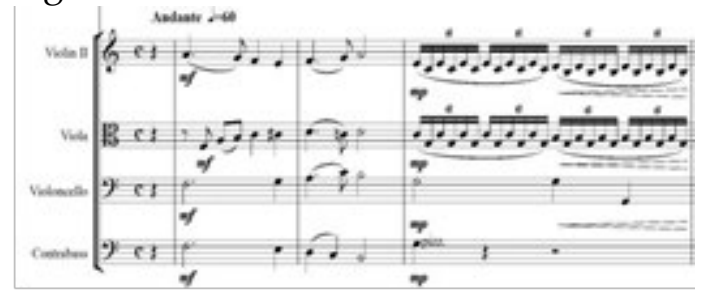

Notasi 15. Seksi gesek sebagai pengiring pada introduksi dengan variasi harmoni, birama 1-3

Berikutnya pada birama 4 dan 5, merupakan bagian peralihan atau transisi dimana instrumen Violin I dan Clarinets dibuat dalam unisono satu oktaf dengan pola ritme seperdelapan bergerak naik dengan memainkan tangga nada $\mathrm{C}$ minor, sedangkan Violoncello dan Bassoon memainkan pola melodi arpeggio yang artinya memainkan nada dari sebuah akord

secara hampir serempak dan membentuk nada-nada penyusun dari akord C minor. 


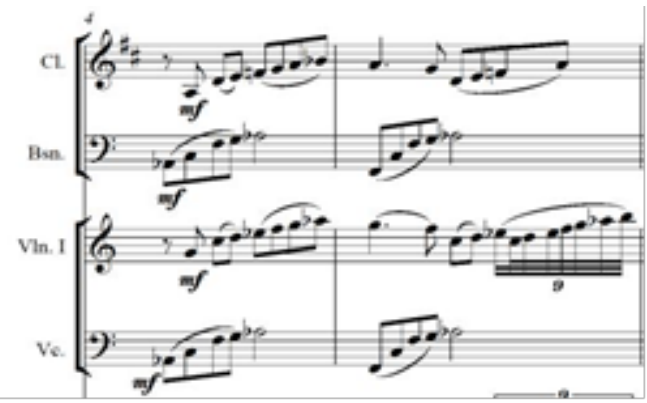

Notasi 16. Melodi transisi dalam akord C minor dengan variasi bebas, birama 4-5

Birama 6 dan 7 merupakan Codetta atau koda kecil yang biasanya terdapat dalam pasasi lagu sebelum lagu berakhir. Pada birama 6 dan 7 dimainkan secara ritardando atau biasa disingkat rit. yang artinya tempo diperlambat secara perlahan, dimana semua instrumen memainkan Perfect Authentic Cadence yakni kadens dengan urutan akord V-I yang dibuat secara suspension. Serta terdapat juga tanda fermata pada birama 7 ketukan ketiga yang artinya perpanjangan nada dengan panjang tak tertentu.

Berikut pengembangan progresi akord yang terjadi pada introduksi sepanjang 7 birama adalah I IV / / vi64 I ii7 / / vii I I64 / / V7 I i / / / iv / / / ii 97 / Vaug V7 I Isus4 / I / I

\section{B.2. Bagian A}

Pada dasarnya bagian A ini merupakan tema pokok dari lagu Tanah Airku karya Ibu Soed aransemen Joko Suprayitno yang dibentuk sepanjang 13 birama yaitu birama 8 sampai dengan birama 20. Aransemen Joko bagian A ini masih sama dengan lagu aslinya yakni terdiri dari tiga bagian diantaranya Periode A, periode B, dan periode $\mathrm{C}$, perbedaannya adalah Joko membuat pengembangan harmoni pada progresi akordnya.

Pada birama 12-15, solo Vokal masih diiringi oleh seksi String dan ada tambahan variasi atau hiasan dari instrumen Flute. Hiasan dari instrumen Flute yang memainkan pola ritmis seperenambelas-an secara staccato atau bermain pendek yang ditandai dengan satu titik diatas atau dibawah dari sebuah not. Violin I dan Violin II memainkan nada pengiring dengan pola ritmis seperenambelas-an sixtuplet dan teknik legato, sedangkan Viola, Violoncello dan Contrabass membentuk pola melodi arppeggio dengan teknik pizzicato. Berlawanan dengan suara dari melodi utama yaitu vokal yang dimainkan secara mengalun dan indah serta suara pengiring dari violin yang terdengar legato.

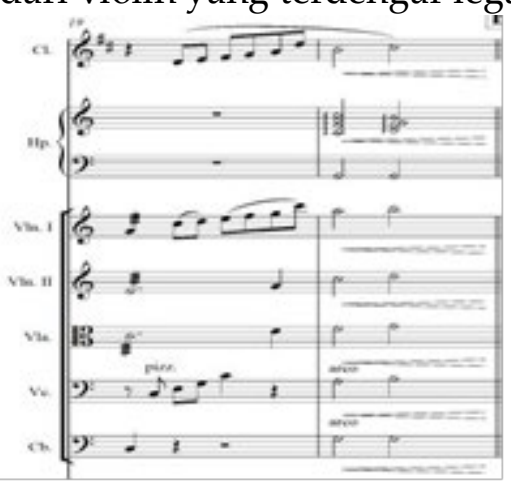

Notasi 17. Transisi variasi bebas, birama 1920

Berikut pengembangan progresi akord yang terapkan pada bagian A lagu Tanah Airku aransemen Joko Suprayitno ini adalah | I I / IV / I I6 / / vi | ii / / V | Isus4 / I / I IV / / | I // / Iii7 / V / I I / / | IV6 I64 IV VI64 | ii Isus4 vii7 / | I64 / V / | I / / / V11 / V7 / I I

\section{B.3. Bagian B}

Kembali ke tema lagu awal dimana Bagian B dinyanyikan dengan syair lagu yang kedua dan mengalami modifikasi lebih dengan penambahan notasi, ritme, serta progresi akord yang berbeda pula namun lebih dinamis. Pada bagian B lirik bait II ini masih dalam tangga nada C Mayor mulai dari birama 21 sampai dengan birama 33 dan masih sama juga seperti pada bagian A lirik bait I diatas yakni terdapat 3 periode atau 3 bagian lagu yakni periode $A$, periode $B$, dan periode $\mathrm{C}$. 
Adapun modulasi yang dibuat dalam aransemen lagu Tanah Airku oleh Joko ini sangat megah dan mengagumkan. Disinilah grafik yang memberi kesan klimaks dari aransemen Joko bahwasannya aransemen awal yang dibuat secara Natural atau nada dasar C Mayor kemudian terjadi modulasi naik 3 kres atau menjadi nada dasar A Mayor. Transisi I ini dibuat dalam dua birama sebagai tanda atau jembatan pemisah yakni pada birama 32 dan birama 33 . Terkecuali Vokal, bagian ini semua instrumen memainkan nadanya masingmasing yang telah dibuat dengan dinamika yang sama yaitu mezzoforte secara energik dan dinamis. Yang pertama dibirama 32 ada Flute, Clarinet memainkan not seperenambelasan unison empat ketuk berturut-turut dalam satu birama secara sixtuplet dan legato yang memberi kesan tegang pada puncak transisi I.

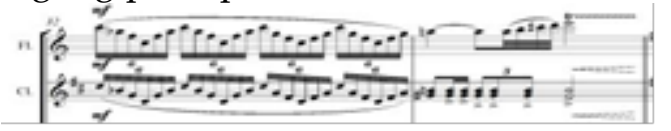

Notasi 18. Figur repitisi terjadi pada transisi dengan variasi bebas, birama 32-33

Serta nada yang kuat dari Strings yang menggunakan nada seperempat panjang dalam satu birama dengan membentuk akord dan sebagai pendukung dari nadanada melodi yang dimainkan oleh instrumen tiup. Cymbals hanya bermain pada birama 32 ketukan pertama yang memberi ketegasan bahwa ini adalah bagian dari puncak klimaks menuju variasi 1 .

Berikut pengembangan progresi akord pada bagian B ini adalah | / I / ii7 / I I6 / vi7 /

$$
\text { | ii7 / V/ | Isus4/I/ I IV / / }
$$

| iii7/vi / | ii/V9/ | I// / | IV I

IV VI | ii Ivii / I I6 $4 / \mathrm{V} /$ | I / /

/I ii7 / V11 / I I

\section{B.4. Bagian C}

Bagian $\mathrm{C}$ merupakan variasi pertama yang dibuat dalam tangga nada A Mayor dan masih terdiri dari 3 bentuk bagian yakni periode $A$, periode $B$, dan periode $C$. Dalam periode $\mathrm{A}$ bagian $\mathrm{C}$ ini dimainkan mulai dari birama 34 sampai dengan birama 37. Disini Violin I, Violin II, dan Viola mendapatkan peran dalam memainkan melodi utama pada tema periode A lagu Tanah Airku dimana terjadi pengembangan pada variasi melodi yang terlihat jelas dibirama 35 dan birama 37.

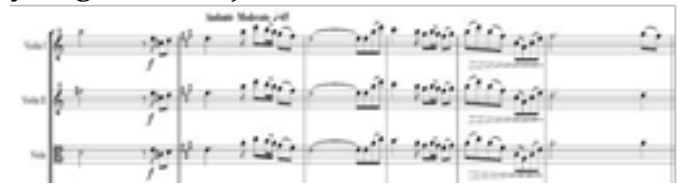

Notasi 19. Tema melodi periode A lagu

Tanah Airku dengan variasi melodi, birama 34-38

Selanjutnya pada birama 45 sampai dengan birama 49 merupakan

transisi dengan mengembangkan akord-akord peralihan menggunakan teknik variasi bebas dalam mengolah sebuah progresi akord. Dalam transisi ini terjadi 3 kali perubahan tangga nada yakni pertama pada birama 45 dan 46 dengan tangga nada C Mayor, kedua pada birama 47 dengan tangga nada Eb Mayor dan yeng ketiga pada birama 48 dan 49 masuk dalam tangga nada D Mayor. Berikut variasi melodi yang dimainkan oleh Oboes dan Bassoons dalam tangga nada C Mayor.

Terdapat juga teknik variasi ritme yang dibawakan oleh seksi Strings dengan memainkan not seperdelapan triplet dalam 2 birama yakni pada birama 45 dan birama 46 .

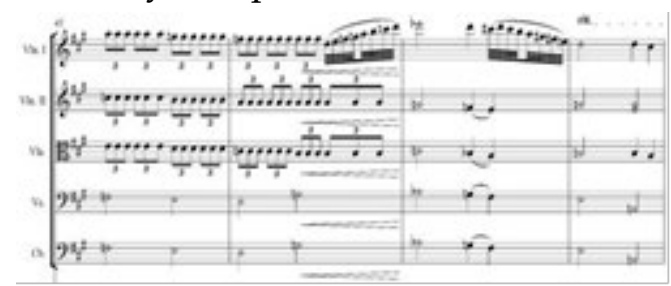

Notasi 20. Teknik variasi ritme dalam tangga nada C Mayor, birama 45-48

Transisi terakhir ada pada birama 48 d an birama 49 dimana tangga nada atau tonika menjadi nada dasar Do $=\mathrm{D}$ Mayor 
dengan teknik variasi harmoni dalam mengembangkan progresi akord. Pada birama 48 dan birama 49, yang bermain adalah seksi tiup kayu, tiup logam dan gesek. Dimainkan dengan secara rit. atau ritardando yang berangsur menjadi lambat dengan dinamika diminuendo seperti ini:

Berikut pengembangan progresi akord pada bagian C ini adalah I I I IV / I iii / / / V / / / vi / V / I IV / / / I9 / I6 / I II7 / V7 / I I / / I IV / / VI64 I ii / vii / I I64 / V / I $(\mathrm{Do}=\mathrm{C}) \mathrm{IV7} / \mathrm{iii7} / \mathrm{I}$ ii7 / V9 / / (Do=Eb) IV7 / iii7 ii\#7 | (Do=D) ii7 / V11 V7 | I / / / |

\section{B.5. Bagian D}

Bagian ini terdiri dari 14 birama dimana tema periode $C$ terdapat dalam 12 birama didepan dan ditambah 2 Coda terakhir serta masih sama dengan bentuk bagian lagu aslinya yakni 3 bentuk bagian periode $A$, periode $B$, periode $C$. Bagian $D$ ini merupakan variasi kedua dalam lagu Tanah Airku aransemen Joko Suprayitno dengan berkembangnya variasi dan dimainkan dalam tangga nada D Mayor. Pada birama 50 sampai dengan birama 53 adalah birama periode A namun dimainkan dengan lirik lagu kedua. Lalu birama 54 sampe 57 adalah kalimat periode B lirik lagu kedua dan birama 58 sampai birama 61 adalah kalimat periode $\mathrm{C}$.

Kalimat periode A kembali lagi dimainkan oleh vokal dengan pembagian 2 suara membentuk harmoni, dimana melodi utama dinyanyikan oleh Binu D. Sukaman sebagai Soprano dengan dipertebal suara terts bawah oleh Aning Katamsi sebagai Mezzosoprano seperti notasi dibawah ini:

Periode A bagian D ini melodi utama yang dimainkan vokal diiringi oleh Horns, Harpa serta seksi gesek dengan membentuk akord pada setiap progresinya. Pengiring pada periode A ini dimainkan dengan dinamika mezzoforte dengan kembali ke tempo semula yakni Andante (60).

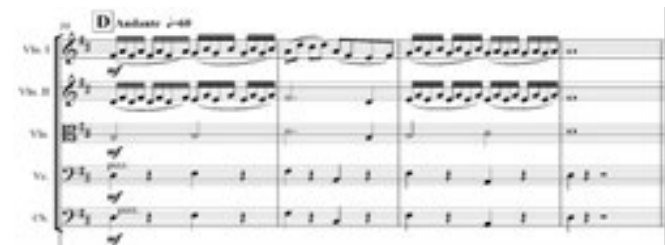

Notasi 21. Melodi pengiring periode A bagian $\mathrm{D}$ variasi harmoni, birama $50-53$

Maka dapat disimpulkan pengembangan progresi akord pada bagian $\mathrm{D}$ diatas adalah I I I / ii / I I6 / / / I II / V7 / I I / / / IV / / / I / / | V7 / V / I I / / | IV IV9 / VI | ii I VII7 / | I64 / V / | I64 / / | II / V7 / I I / / | |

\section{Penutup}

Komposisi lagu Tanah Airku karya Ibu Soed yang bisa dibilang cukup singkat ini dapat dikembangkan oleh Joko menjadi lebih kompleks yakni 6 bagian dan 4 variasi. Keistimewaan aransemen Joko Suprayitno ini adalah Joko lebih memfokuskan pada setiap melodi utamanya dengan konsep dalam melodi yang indah tersebut digubah secara rapi pada setiap bagiannya dan dibuat menjadi lebih bagus lagi dengan cara memberi dukungan secara musikal.

Joko menuangkan ide-ide musikalnya kedalam aransemen lagu Tanah Airku ini yakni dengan menggunakan beberapa teknik variasi dan menyertakan elemen orkestrasi musik barat serta dinyanyikan oleh vokal seriosa. Aransemen Joko Suprayitno dapat dikatakan 6 bagian karena didalamnya terdapat introduksi, bagian A (lirik bait I), bagian B (lirik bait II), bagian $C$ (interlude) $D_{o}=A$, bagian $D$ (lirik bait II) Do=D, dan coda. Kemudian terdapat 4 teknik variasi dalam aransemennya yakni variasi harmoni, variasi melodi, variasi irama dan variasi bebas.

\section{Referensi}

Kawakami, Genichi. 1975. Arrangging Popular Music: A Practical 
40 ] Puput Meinis Narselina, dkk.: Analisis Bentuk Musikal dan Struktur Lagu Tanah Airku

Guide, Yamaha Music Foundation, Tokyo, Japan.

Prier sj, Karl-Edmund. 2004. Ilmu Bentuk Musik, Pusat Musik Liturgi, Yogyakarta.

Stein, Leon. 1979. Structure and Style: The Study and Analysis of

Musical Forms.Summy-Birchard Music, New Jersey.

Wibowo, Joko. 2013. Lagu Wajib Nasional dan Daerah. Redaksi Tiara Pustaka, Yogyakarta. 